\title{
HUBUNGAN RENTANG UKURAN BUTIR TERHADAP BESARAN BATUAN
}

\author{
Siti Sarah Munifah a), Siska Nuraidah, Siti Marya Darmawati, Selly Feranie ${ }^{\text {b) }}$ \\ Departemen Pendidikan Fisika FPMIPA UPI Jl. Dr. Setiabudi No 299, Bandung 40154 \\ Email: a)sitisarahmunifah@gmail.com, b)feranie@upi.edu
}

\begin{abstract}
Abstrak
Batuan berpori merupakan benda padat yang memiliki rongga-rongga (pori). Kualitas batuan dapat ditentukan oleh berbagai kriteria diantaranya, porositas, luasan butiran spesifik, dan permeabilitas butiran. Porositas adalah kemampuan untuk menyimpan, sedangkan permeabilitas atau kelulusan yaitu kemampuan untuk melepaskan fluida tanpa merusak partikel pembentuk atau kerangka batuan ${ }^{1}$. Luas permukaan spesifik merupakan perbandingan antara luas permukaan terhadap volume atau berat suatu bahan ${ }^{2}$. Kriteria tersebut menunjukkan kriteria pori yang akan terisi oleh fluida baik berupa cairan, gas, atau senyawa hidrokarbon. Kriteria tersebut ternyata dipengaruhi oleh ukuran butir yang menempati ruangan batuan tersebut. Teknik pemodelan dilakukan dalam penelitian ini untuk membantu memahami pengaruh rentang ukuran butir terhadap kriteria-kriteria tersebut. Pemodelan dilakukan dengan menggunakan random penetrable sphere packing yang merepresentasikan model paling sederhana dari batuan sedimen. Simpulan dari pemodelan yang dilakukan menunjukkan bahwa semakin besar rentang ukuran butir maka porositas dan permeabilitas batuan akan semakin kecil, sedangkan luasan permukaan spesifiknya akan semakin besar. Apabila rentang ukuran butir diperbesar yang berarti bahwa kemungkinan butir yang menempati batuan tersebut lebih banyak memiliki variasi ukuran, maka memungkinkan daerah batuan tersebut terisi oleh butir-butir dengan ukuran yang lebih besar, sehingga akan menghasilkan porositas dan permeabilitas batuan yang semakin kecil serta luasan permukaan spesifiknya yang semakin besar.
\end{abstract}

Kata-kata kunci: pemodelan batuan berpori, porositas, permeabilitas, luasan permukaan spesifik

\begin{abstract}
Porous rock composed of solid material and pores. Rock quality can be determined by various aspects as porosity, specific surface area and permeability which are affected by the size of grain occupying space on the rock. Rock model was then done by random penetrable sphere packing method which represent the simplest form of rock. Porosity is the ability to reserve, meanwhile permeability is the ability to deliver fluids without wrecking the rock structure. Specific surface area is the ratio of surface area with material mass or volume. The greater the variety of grain used, the smaller the value of porosity and permeability are, because of the rock spaces occupied will be larger. Thus, the value of specific surface area will increase.
\end{abstract}

Keywords: porous rock models, porosity, permeability, specific surface area 


\section{PENDAHULUAN}

Batuan berpori merupakan benda padat berongga (pori) yang dapat terisi oleh fluida seperti cairan, gas, atau senyawa hidrokarbon. Karakteristik batuan diantaranya adalah porositas, luas permukaan spesifik, dan permeabilitas. Dalam batuan berpori, porositas $(\phi)$ dapat didefinisikan sebagai variabel untuk mengetahui besarnya kemampuan untuk menyimpan fluida pada batuan. Luas permukaan spesifik $\left(\mathrm{S}_{\mathrm{A}}\right)$ merupakan perbandingan antara luas permukaan terhadap volume atau berat suatu bahan [2]. Permeabilitas $(k)$ merupakan sebuah variabel untuk menentukan besarnya kemampuan fluida mengalir dalam batuan. Dalam hal ini, permeabilitas memiliki hubungan dengan tekanan fluida yang mengalir pada pori batuan.

Dalam karakterisasinya, batuan dapat dianggap tersusun atas butir-butir berbentuk bola yang memiliki ukuran yang bergantung pada jari-jari butir tersebut. Distribusi butir-butir ini pada batuan memiliki pengaruh terhadap karakteristik tersebut. Telah banyak dilakukan penelitian mengenai hal tersebut diantaranya, penelitian untuk menganalisis permeabilitas batuan dengan menggunakan teknik analitik yang dilakukan oleh Chan (2013)[5], penelitian mengenai luas permukaan spesifik pada bubuk keramik yang disintering oleh Martin (1998)[6], penelitian mengenai porositas pada butiran pasir yang dilakukan oleh Naomi (2015)[7], penelitian mengenai struktur pori batuan dengan fraktal dilakukan oleh Feranie (2010)[3], serta penelitian mengenai pengaruh ukuran butir terhadap porositas dan permeabilitas pada batu pasir yang dilakukan oleh Nurwidyanto (2006)[1].

Dalam tulisan ini, pemodelan batuan berpori dilakukan menggunakan teknik random penetrable sphere packing yang sebelumnya telah dilakukan oleh Firmansyah (2014)[8] untuk menentukan tortositas batuan berpori. Teknik ini merepresentasikan model batuan paling sederhana dari batuan sendimen. Pemodelan batuan menggunakan teknik ini dapat dilakukan menggunakan software Matlab untuk mengetahui hubungan antara rentang ukuran butir batuan dengan porositas, permeabilitas, dan luas permukaan spesifik.

\section{METODE PENELITIAN}

Dilakukan pemodelan batuan berpori 3D berukuran $200 \times 200 \times 200$ yang akan diisi oleh butiran batuan berjumlah 200 buah. Variasi rentang jari-jari butiran batuan yang digunakan dimulai dari 5, 10, 15, 20, dan 25 dengan jari-jari minimum butiran (dibuat tetap) yaitu 5. Jari-jari butiran maksimum bergantung pada rentang jari-jari yang dipilih. Pemodelan dilakukan menggunakan metode random penetrable sphere packing, sehingga ukuran butiran yang didistribusikan pada model batuan berpori akan dipilih secara acak. Dibuat 10 model dari tiap rentang jari-jari yang dipilih. Karakteristik model batuan dari berbagai variasi rentang jari-jari butiran dianalisis melalui citra 2D dan 3D. Perhitungan persentase porositas dilakukan dengan membandingkan volume pori terhadap volume keseluruhan batuan yang dinyatakan dalam persamaan (1).

$$
\Phi=\frac{\text { wolume pori }}{\text { wolume total }} x 100 \%
$$

Sedangkan perhitungan luas permukaan spesifik dapat dilakukan menggunakan persamaan (2).

$$
S_{A}=\frac{\text { Tuas permukaan }}{\text { volume total }} \times 100 \%
$$

Perhitungan permeabilitas menggunakan persamaan Kozeni Carman yang dinyatakan oleh persamaan (3).

$$
k=\frac{\phi^{3}}{\operatorname{ct}^{2} A}
$$

Keterangan :

$\begin{array}{ll}\Phi & =\text { Porositas } \\ S_{A} & =\text { Luas permukaan spesifik }\end{array}$




$$
\begin{array}{ll}
\mathrm{k} & =\text { Permeabilitas } \\
\tau & =\text { Tortositas } \\
\mathrm{C} & =\text { Nilai densitas kuarsa }
\end{array}
$$

Pada pemodelan ini digunakan nilai tortositas dan densitas kuarsa yang tetap. Nilai tortositas yang digunakan adalah $\tau=1.5$ dan nilai densitas kuarsa $\mathrm{c}=2$, karena butir yang menyusun batuan diasumsikan berbentuk bola.

\section{HASIL DAN PEMBAHASAN}

\subsection{Pencitraan model batuan}

Pemodelan batuan dengan teknik random penetrable sphere packing yang dilakukan menggunakan software Matlab dan Fiji menghasilkan pencitraan 2D dan 3D dari 5 rentang jari-jari butir yang berbeda.

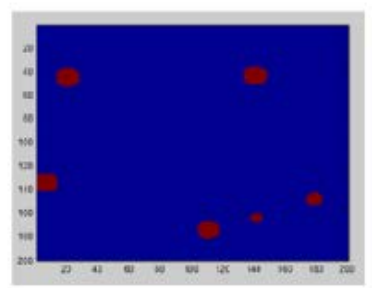

(a)

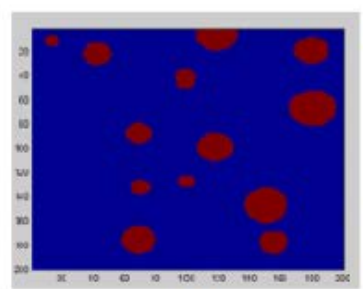

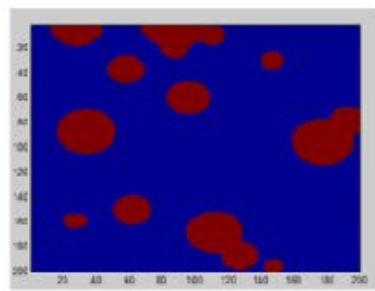

(c)

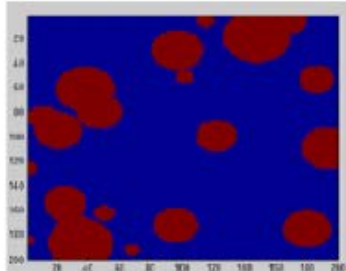

(d)

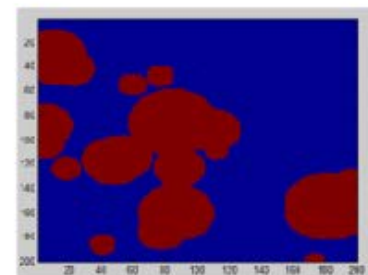

(e)

GAMBAR 1. Citra 2D dari berbagai rentang jari-jari butiran (a) $\Delta \mathrm{r}=5$, (b) $\Delta \mathrm{r}=10$, (c) $\Delta \mathrm{r}=15$, (d) $\Delta \mathrm{r}=20$, dan (e) $\Delta \mathrm{r}=25$

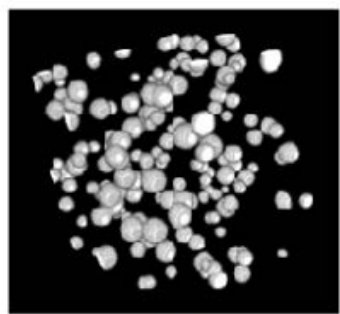

(a)

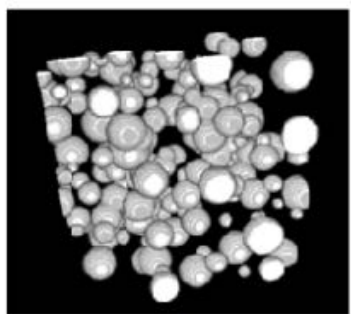

(b)

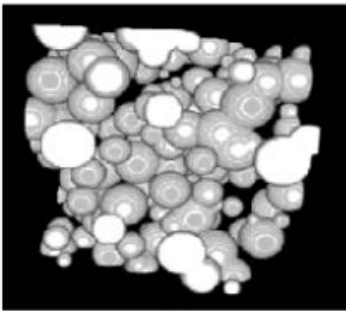

(c)

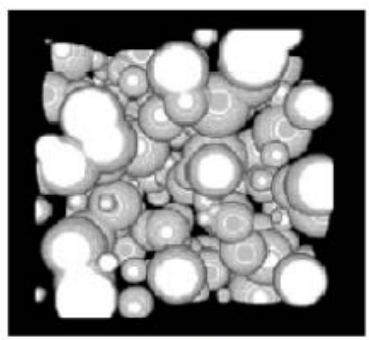

(d)

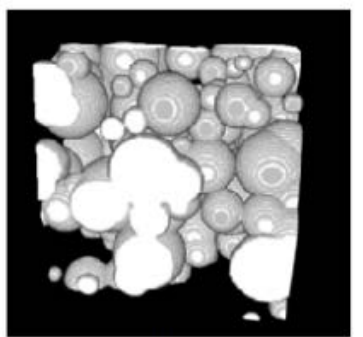

(e)

GAMBAR 2. Citra 3D dari berbagai rentang jari-jari butiran (a) $\Delta \mathrm{r}=5$, (b) $\Delta \mathrm{r}=10$, (c) $\Delta \mathrm{r}=15$, (d) $\Delta \mathrm{r}=20$, dan (e) $\Delta \mathrm{r}=25$ 


\subsection{Pengaruh ukuran butir terhadap karakteristik batuan}

Dari hasil pemodelan tersebut didapatkan nilai rata-rata porositas, luas permukaan spesifik, dan permeabilitas untuk setiap rentang jari-jari butir yang berbeda beserta standar deviasinya yang menunjukkan tingkat presisi data yang ditunjukan pada TABEL 1.

TABEL 1. Rata-rata porositas, luas permukaan spesifik, dan permeabilitas 10 model batuan dari tiap rentang jari-jari butir beserta standar deviasinya.

\begin{tabular}{ccccccc}
\hline$\Delta r$ & $\bar{\Phi}$ & $S D_{\bar{\Phi}}$ & $\overline{S_{A}}$ & $S D_{\overline{S_{A}}}$ & $\bar{k}$ & $S D_{\bar{k}}$ \\
\hline 5 & 0.95927 & 0.002429 & 0.01325 & 0.000499 & 1098.907 & 85.8551 \\
10 & 0.88387 & 0.006901 & 0.02316 & 0.000932 & 287.9048 & 31.20264 \\
15 & 0.77275 & 0.010974 & 0.03362 & 0.001542 & 91.4446 & 10.97563 \\
20 & 0.62778 & 0.028855 & 0.04131 & 0.00119 & 32.6831 & 5.874193 \\
25 & 0.49395 & 0.032072 & 0.04396 & 0.00236 & 14.2751 & 3.88048 \\
\hline
\end{tabular}

Data tersebut diplot ke dalam grafik untuk melihat hubungan karakteristik batuan dengan rentang jari-jari butir. GAMBAR 3 menunjukkan bahwa semakin besar rentang jari-jari butir maka kemungkinan ukuran butir yang menempati batuan akan semakin bervariasi, sehingga tempat untuk menyimpan fluida akan semakin kecil yang diindikasikan dengan mengecilnya nilai porositas yang dihasilkan. Hasil ini sesuai dengan hasil penelitian yang telah dilakukan oleh Feranie (2010)[3] yang menunjukkan bahwa porositas batuan dipengaruhi oleh distribusi ukuran pori dan hasil penelitian yang dilakukan oleh Naomi (2015)[7] menunjukan bahwa porositas meningkat seiring penurunan ukuran butir. Grafik ini menggunakan regresi linear karena memiliki nilai korelasi yang cukup besar, yaitu $\mathrm{R}^{2}=0.9842$.

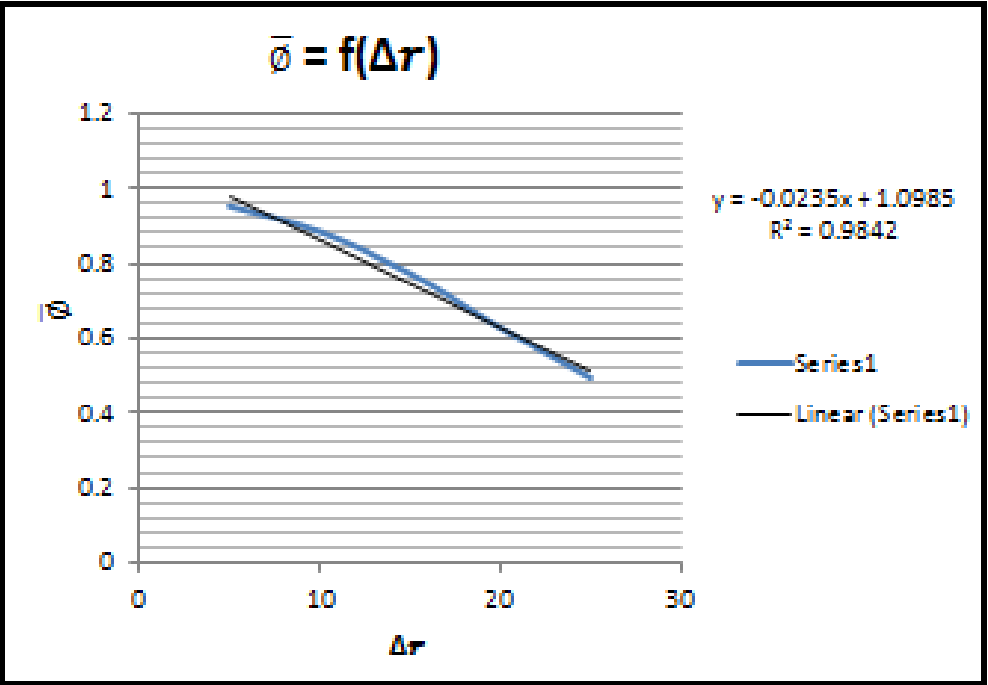

GAMBAR 3. Pengaruh rentang jari-jari butiran terhadap porositas batuan

Begitu juga pada GAMBAR 4, ditunjukan bahwa semakin besar rentang jari-jari butir maka semakin kecil pula kemampuan batuan untuk melepaskan fluida tanpa merusak partikel pembentuk atau kerangka batuan yang diindikasikan dengan semakin kecilnya nilai permeabilitas yang dihasilkan. 


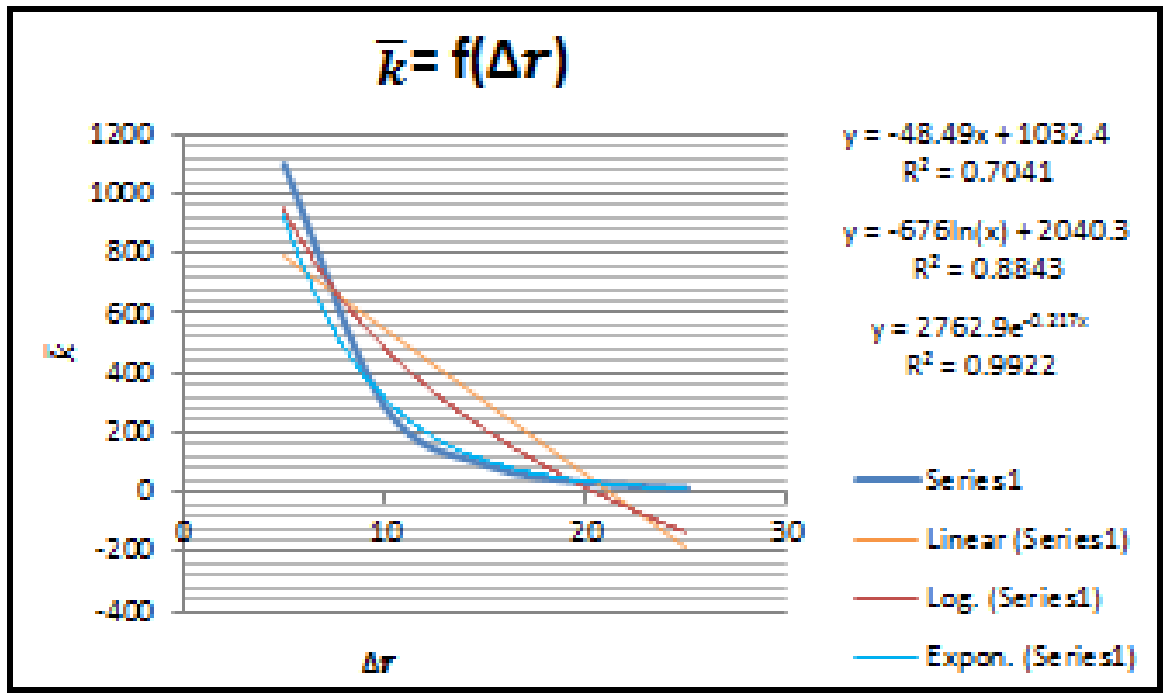

GAMBAR 4. Pengaruh rentang jari-jari butiran terhadap permeabilitas batuan

Namun pada grafik ini, korelasi terbesar ditunjukkan dengan kubungan eksponensial dengan nilai $\mathrm{R}^{2}=0.9922$. Sehingga didapatkan bahwa permeabilitas batuan menurun secara eksponensial untuk peningkatan nilai jari-jari butiran. Hasil ini sesuai dengan hasil penelitian oleh Byon (2013)[5] yang menunjukkan bahwa permeabilitas menurun secara kuasi-linier untuk peningkatan ukuran partikel yang terdistribusi.

Berbeda dengan dua gambar sebelumnya, GAMBAR 5 menyatakan bahwa luas permukaan spesifik akan semakin besar pula ketika rentang jari-jari butiran diperbesar. Hal ini disebabkan semakin besar rentang jari-jari butir maka kemungkinan luasan butir batuan dalam volume total batuan juga semakin besar. Grafik ini juga menggunakan regresi linear karena memiliki nilai korelasi yang cukup besar, yaitu $\mathrm{R}^{2}=0.9628$.

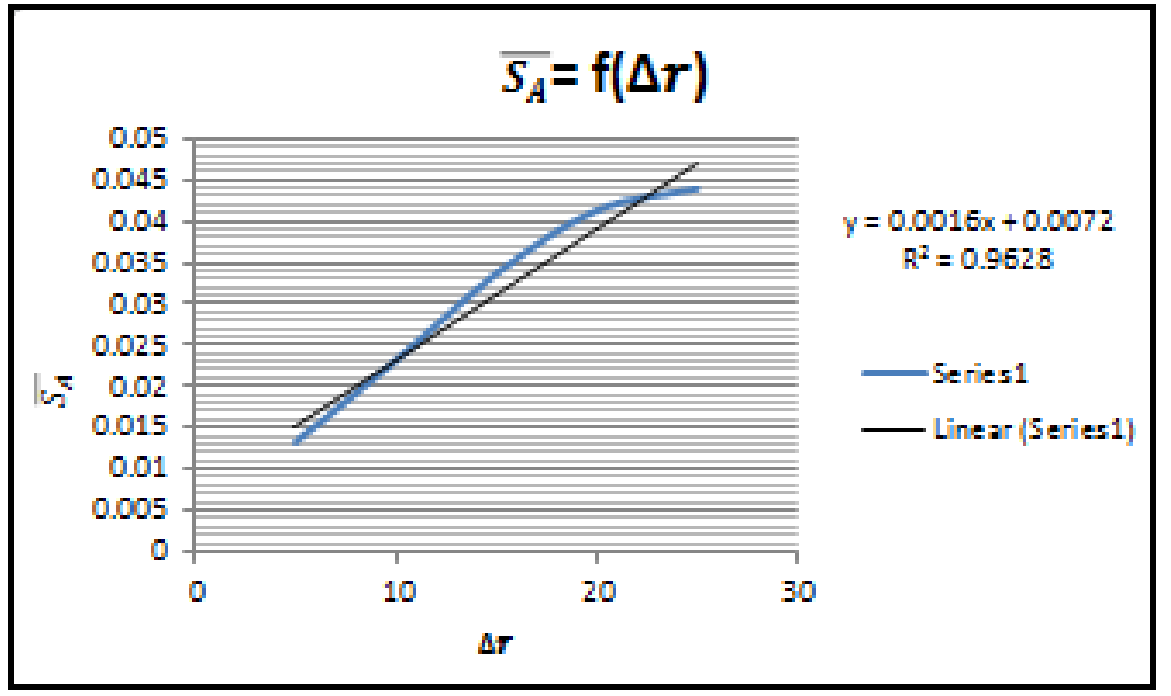

GAMBAR 5. Pengaruh rentang jari-jari butiran terhadap luas spesifik batuan

Hasil berikut juga sesuai dengan hasil penelitian oleh Martin (1998)[6] yang menunjukkan bahwa ukuran partikel yang lebih besar menghasilkan peningkatan nilai luas permukaan spesifik yang signifikan. 


\section{SIMPULAN}

Pemodelan batuan sukses dilakukan menggunakan software MATLAB. Pada pemodelan batuan tersebut dapat diketahui bahwa semakin besar ukuran butir, maka porositas dan permeabilitas batuan akan semakin kecil, sedangkan luasan permukaan spesifiknya akan semakin besar. Apabila rentang ukuran butir diperbesar, diperkirakan butir yang menempati batuan tersebut lebih banyak memiliki variasi ukuran, maka memungkinkan daerah batuan tersebut terisi oleh butir-butir dengan ukuran yang lebih besar, sehingga akan menghasilkan porositas dan permeabilitas batuan yang semakin kecil, serta luasan permukaan spesifiknya yang semakin besar.

\section{UCAPAN TERIMAKASIH}

Kami selaku penulis mengucapkan terima kasih kepada dr. Fourier Dzar Eljabbar Latief, M.Si. atas segala masukan dan bimbingannya dalam pembuatan model batuan dan penyempurnaan tulisan ini.

\section{REFERENSI}

[1] Nurwidyanto, M. Irham, Ita Noviyanti, and Sugeng Widodo. "Estimasi Hubungan Porositas dan Permeabilitas pada Batupasir (Study Kasus Formasi Kerek, Ledok, Selorejo)." BERKALA FISIKA 8.3 (2005): 87-90

[2] Wiqoyah, Qunik. "Pengaruh kadar kapur, waktu perawatan dan perendaman terhadap kuat dukung tanah lempung." (2006).

[3] Ferani.S, (2010), Pemodelan Struktur Pori dari Batuan Geologi Fractal, Berkala Fisika Vol. 12, No. 3, Juli 2010

[4] A.Firmansyah, (2007), Dasar dasar Pemograman Matlab

[5] Byon.C, (2013) The effect of the particle size distribution and packing structure on the permeability of sintered porous wicks, International Journal of Heat and Mass Transfer 61 (2013) 499-504

[6] Martin.L.P, (1998) Effect of particle size distribution upon specific surface area and ultrasonic velocity in sintered ceramic powders, Materials Science and Engineering A246 (1998) 151-160

[7] Naomi A. Ogolo, (2015), Effect of Grain Size on Porosity Revisited, Society of Petroleum Engineers SPE-178296-MS

[8] Firmansyah, (2014), Tortositas pada Model 3D Batuan Berpori, Jurnal Spektra Vol 15, No 2 (2014): Spektra: Jurnal Fisika dan Aplikasinya 